\title{
Implementation of the Constitutional Court Decision Number 18 / PUU-XVII / 2019 Towards Consumer Financing Institutions
}

\author{
Sundaru Guntur Wibowo ${ }^{1}$, Hedy Pandowo ${ }^{2}$, Ahmad Khudori ${ }^{3}$, Galuh Try Prawesti ${ }^{4}$ \\ State Polytechnic od Madiun, Jalan Serayu No. 84 Madiun, East Java, Indonesia ${ }^{1,2,3,4}$
}

\begin{abstract}
The purpose of this research is to know and understand the implementation of consumer financing agreements and to solve problems that arise if there is default by the debtor in the implementation of the consumer financing agreement. This research is specific to the handling of late payments or even bad credit, which then the object of the agreement is executed / withdrawn by the debitor in relation to the Constitutional Court (MK) Decision Number 18 / PUU-XVII / 2019 which stipulates that the execution of fiduciary guarantees must obtain permission from the court., meanwhile, the consumer financing agreement is equipped with a fiduciary certificate which has the power of execution. This becomes interesting to research so that it provides understanding for the parties concerned. This study uses a normative approach, using primary data and secondary data which are then analyzed using qualitative analysis techniques.
\end{abstract}

Keywords: Consumer Financing, Payment Default

\section{Introduction}

The development of the national automotive world and solutions to the high demand for motorized vehicles and other consumer goods have made the financial business of consumer financing institutions a choice. Some National banks have even expanded their business by opening this business unit. The consumer finance business is still in great demand by the public because of the ease of requirements. One example of an activity in the financial institution business sector is a finance company which is a non-bank financial institution. The forms of business activities of the Financing Company include:
a) Leasing
b) Factoring
c) Credit card business
d) Consumer finance
e) Venture capital
f) Trading in securities

The reason for effective and efficient service is that finance companies always use standard contracts, this is because the number of consumers who are given credit facilities is very large, so it will take a long time if it does not use standard contracts. Article 1313 of the Civil Code states that: 
"An agreement is an act in which one or more people bind itself to one or more people" [1].

Furthermore, Article 1320 of the Civil Code states 4 conditions for the validity of the agreement, namely: a) There is an agreement that those who tie themselves, b) The ability to make engagements, c) Certain things, d) A cause that is lawful.

Article 1320 of the Civil Code which is the principle of consesualism, namely where the agreement is valid if there is an agreement. This is related to Article 1338 paragraph (1) of the Civil Code which is also the principle of freedom of contract, so that the agreement is binding on the parties because it creates rights and obligations for the parties themselves.

A good assessment of the party who will carry out the contents of the agreement is appropriateness. Where appropriateness is good faith that must be fulfilled in applying the principle of freedom of contract. This has been regulated in Article 1338 paragraph (3) of the Civil Code [1]. The principle of good faith implies that the parties have the freedom to make agreements according to their wishes, but good faith limits the agreement.

In implementing consumer financing agreements, generally the agreement is set out in the form of a standard agreement. Where the clause in the standard agreement is made by one party and the other party only signs the agreement that has been made. If the party, in this case the consumer or debtor, does not sign the standard agreement, the consumer will not get the goods which are the object of the agreement. Consumer financing is an agreement based on the principle of freedom of contract as the main principle of contract law. As regulated in Article 1338 Juncto Article 1320 of the Civil Code [1].

In implementing the agreement, business actors generally have a stronger position than consumers who tend to have a weaker position. So that the weak party only has two choices, namely if the consumer needs the services or goods offered to him, then he must agree to all the terms and comply with the proposed agreement regardless of whether the consumer knows and or understands the clause of the agreement or not, and if they do not approve or do not agree on the terms proposed to him, then they must cancel or not enter into an agreement with the said business actor, so generally the business actor is not clear in explaining the contents of the agreement.

Standard agreements often find the inclusion of clauses that regulate how to resolve disputes and exoneration clauses, namely clauses that contain conditions that limit or even completely eliminate a responsibility that should be borne by the business actor. Even though there is a license for leasing and selling activities buy installments and rent. The arrangement is not explained in detail regarding the position of the buyer and the lessee.

Practices in agreements, leasing institutions or finance companies have a strong position when compared to buyers or their customers, this is because there is a risk that the finance company does not want to take if there are obstacles to not paying installments that have been set by both parties. Then a clause was drawn up that gave the finance company the right to demand and withdraw goods according to the agreement it did.

If a problem occurs, it is certain that what is drawn is the object of the agreement, whether it is made by an employee of the company or using the services of a third party. The problem that then arises is that for the object of collateral (motorbike) that is withdrawn, the debtor or consumer who wants the motorbike to become his again is that the consumer is given the choice:

a) Pay all arrears (installments and fines) plus the administrative execution fee (repo fee)

b) Consumers can continue installments by paying installments in arrears, fines and additional execution administrative costs (repo fees), so consumers do not have to pay off all outstanding obligations (Continue Pay) 
The problem that arises and develops at this time is that creditors in withdrawing the object of the agreement are increasingly blind, they work with external debt collectors who do not understand the debtor's payment history, they only know the debtor is late and withdraws the object of financing wherever they are. The basis for making a withdrawal can actually be justified if the agreement has been registered until the issuance of a fiduciary certificate, because the value is the same as a court decision, there is executorial power and has a parate of execution. In fact, in one branch office of a finance company the number of bad loans reaches thousands, so that the withdrawals made on the road are more effective, because generally the object of financing has been transferred, and if it has to go through a fairly long civil court process, it is not proportional to the value of the object of financing. Often the object of the agreement has been stripped down or the spare part has been replaced with a fake.

Increasingly unrest arises in the community because the withdrawals made tend to use violence and threats, where this has entered the realm of criminal law, on that basis the state then tries to be present by providing directions in the form of Constitutional Court (MK) Decision Number 18 / PUU-XVII / 2019 against consumer financing institutions, in this decision the creditor must obtain a court order in making the withdrawal of the object of financing, or the creditor can make a direct withdrawal if, first the debtor voluntarily gives up his vehicle, the two debtors admit that he is in default [2].

\section{Method}

The term methodology comes from the word Method, according to the custom the method is formulated with the following possibilities:

a) A type of thinking used in research and assessment;

b) A technique common to science;

c) Certain ways to carry out a procedure.

Research is an effort to obtain facts or principles (finding, developing, testing the truth) by collecting and analyzing data (information) which is carried out carefully, clearly, systematically and can be accounted for (scientific method) [3]. This research is a field research or often called empirical juridical legal research. The specification used in this research is a case study research with a descriptive analytical description of what is currently applicable and what should be. The specification in this study is descriptive, because the data obtained from the study tries to provide an overview of the process and about the problems that exist in the implementation of the leasing agreement and analyze it so that it is a general conclusion.

Based on the formulation of the problem and research objectives, the approach method used is the juridical empirical approach method. The empirical juridical approach method is an approach that examines secondary data first and then continues by conducting primary data research in the field. The juridical factor is a set of civil law rules in general and regulations relating to the field of contract law as a branch of law and is closely related to the material of this research, while the empirical factor is the consumer finance company that makes agreements with consumers.

The location of research in finding data is a finance company in Madiun which is related and relevant to the material discussed. Subjects and objects in this study are consumer finance companies, as research subjects because they are companies that enter into consumer 
financing agreements. As an object of research because in this company the authors get the data. The respondents in this study were as follows:

a. Employees of financing companies

b. Debtors

The data collected includes primary data and secondary data.

1) Primary data, is data obtained directly from the source, observed and recorded for the first time. In this study, primary data was collected by means of interviews conducted with company leaders, the legal division of the leasing company, consumers who experienced problems according to predetermined themes as respondents in this study. Interviews were conducted using a list of questions. From the preparation of this list of questions, it is hoped that the process of question and answer will be smooth and obtain data and information.

2) Secondary data, is data acquisition with document studies which include:

a. Primary Legal Materials are binding legal materials consisting of:

1. Civil Code [1];

2. Presidential Decree Number 61 of 1988 concerning Financing Institutions [4];

3. Decree of the Minister of Finance of the Republic of Indonesia Number: 446 / KMK.017 / 1988 concerning Provisions and Procedures for Implementing Financing Institutions [5];

4. Decree of the Minister of Finance of the Republic of Indonesia Number $172 /$ KMK.06 / 2002 concerning Financing Companies [6];

5. Financial Services Authority Regulation, POJK No: 1 / POJK.07 / 2013 [7].

b. Secondary Legal Materials are legal materials that provide an explanation of primary legal materials consisting of books on consumer financing agreements, fiduciary guarantees.

The techniques in obtaining data used by the author are:

1) Primary data is obtained from:

Field data collection was carried out by means of interviews, both structured and unstructured. Structured interviews are carried out based on the list of questions provided by the researcher, while unstructured interviews are interviews which are conducted without being guided by questions, but are expected to develop in accordance with the answers and the situation that is taking place. Observation is, the researcher before conducting the interview first makes observations on the finance company.

2) Secondary Data

Secondary data is obtained from searching library materials such as books and laws and other regulations.

The data analysis in this study was carried out qualitatively, that is, all data obtained were then arranged systematically and analyzed qualitatively, in order to achieve clarity on the issues to be discussed. Qualitative data analysis is a research method that produces analytical descriptive data, namely what is stated by the respondent in writing or orally and their real behavior is thoroughly researched and studied.

The definition of analysis is intended as an explanation and interpretation in a logical, systematic manner. Systematic logic shows inductive thinking and follows discipline in writing scientific research reports. After the data analysis is complete, the results will be presented descriptively, namely by telling and describing what it is in accordance with the problem under study. From these results, a conclusion is drawn which is the answer to the problems raised in this study. 


\section{Result and Discussion}

Implications of the Decision of the Constitutional Court (MK) Number 18 / PUU-XVII / 2019 for consumer financing institutions. Decision of the Constitutional Court (MK) Number 18 / PUU-XVII / 2019 states that Article 15 paragraphs (2) and (3) as well as the Elucidation of Article 15 paragraph (2) of Law Number 42 of 1999 concerning Fiduciary Guarantee apply conditionally unconstitutional unconstitutional) [2]. That are:

a) The terms of default / default must be agreed upon between the creditor and the debtor.

b) if the debtor defaults / defaults on his promises, the debtor must voluntarily submit his guarantee.

c) If the debtor is unable to deliver the guarantee (insistence on submitting the guarantee), he cannot be forced, but must go through a lawsuit to the district court / execution of the fiduciary guarantee certificate.

So that the Constitutional Court's decision has obliged the parties to the consumer financing agreement in making a fiduciary guarantee deed (notary) agreement to make a clause:

a) Default agreement.

b) Agreement and the debtor's volunteerism to submit guarantees to the creditor if the debtor is in default / default.

So, there must be a change in the fiduciary guarantee deed relating to the three things mentioned above. The opinion of the Chairperson of APPI on February 11, 2020, said that the Constitutional Court (MK) decision related to the object of the Fiduciary Guarantee is not a "doomsday" for leasing companies (multi). Multi-finance companies that involve Rp443 trillion in business and involve the motorcycle and car industries which are full of labor must be strengthened [8]. The Constitutional Court decision related to fiduciary seems to emphasize that the execution of bail must go through the court. In fact, leasing can still attract vehicles.

According to Suwandi Wiratno, Chairman of the Indonesian Financial Services Association (APPI), the Constitutional Court's decision makes it clearer. The Constitutional Court's decision clarifies Article 15 of Law (UU) No. 42 of 1999 concerning Default or Default between Debtors and Creditors. So, leasing can still pull vehicles from bad debtors who have previously been warned. With a note, the procedure has been executed [8].

Currently there is confusion in society after the Constitutional Court Decision No. 18 / PUU-XVII / 2019 dated January 6, 2020 regarding Fiduciary, that it is as if the holder of the fiduciary right (leasing) may not carry out the execution himself, but must submit a request for execution to the district court. In fact, this is not the case. Leasing companies can still withdraw vehicles from bad debtors without trial. The Constitutional Court's decision cannot be read in bits and pieces. There is wide scope for executing the bad debtor guarantee.

Just consider the sound of the Constitutional Court's decision, the leasing company can still carry out the execution without going through the court on the condition that the debtor acknowledges that there is default. "As long as the fiduciary right (debtor) has acknowledged the existence of 'default' (default) and voluntarily surrendered the object which is the object of the fiduciary agreement, it becomes the full authority for the fiduciary recipient (creditor) to be able to carry out his own execution (parate execution)". That was the sound of the Constitutional Court decision.

The Constitutional Court's decision also stated that regarding the expectation between the debtor and creditor, there must be an agreement beforehand to determine what kind of conditions make the default. So, there is a previous agreement, how much is the loan, how 
much interest must be paid, including the period. Also, the deadline for installment payments, what if you don't pay the installments, and how much is the fine.

So far, the leasing company business model has only relied on certain down payments (DP), with a BPKB guarantee on behalf of the debtor. Imagine, with only a down payment of $10 \%$ or less, someone can already bring a vehicle, even though the BPKB is as collateral on behalf of the debtor. If there is a default, the creditor will execute it as a fiduciary.

Problems arise when the debtor does not pay installments and is stuck. And, in practice, sometimes it involves a third party to tow the vehicle until excess occurs. However, sometimes this bad debtor is difficult to contact and is not cooperative and maintains his vehicle, even though he has neglected to pay his obligations. There is also a bad debtor asking for protection from "NGOs" so that they are not chased by third parties.

So far, leasing companies have classified four categories of bad debtors: (1) existing customers, units (motorbikes / cars) available; (2) existing customers, unit (motorbikes / cars) does not exist; (3) there is no customer, the unit (motorcycle / car) is available; (4) there is no customer, the unit (motorcycle / car) does not exist. So, for categories 2, 3, and 4, of course, they cannot go through the court, even though these debtors are stuck and have not paid off, and cause losses to leasing. There are units that are lost, sold or pawned.

According to the records of the Infobank Research Bureau, the distribution of finance for multi-finance companies until June 2019 reached IDR 463.38 trillion or grew by around $4.47 \%$ from June 2018 which reached IDR 443.54 trillion. As much as $22 \%$ of it was distributed to two-wheeled vehicles and $41.6 \%$ to four-wheeled vehicles. The rest is channeled for other consumer goods, productive goods, infrastructure, services and accounts receivable [9].

For assets, the total assets of multi-finance companies in Indonesia grew by $2.77 \%$ in June 2019 (year on year). Total assets in June 2018 were recorded at IDR 499.3 trillion, while in June 2019 it was IDR 513.2 trillion. Non performing financing (NPF) of multi-finance companies is still maintained, namely in the range of $2.75 \%-2.89 \%$.

With the Constitutional Court's decision regarding fiduciary, multi-finance companies are likely to be more selective in providing financing. It could be that the DP is increased, then risk management is tightened. Of course, it is no longer easy for multi-finance companies to provide financing. The positive effect of the Constitutional Court's decision, multi-finance companies will be more careful. Maintaining more quality, with potential debtors and low risk. No more jorjoran fights and DP sales.

The negative effect, if there is a slowdown, finance companies, especially the automotive sector, will also be affected and in the end will disrupt economic growth. The automotiverelated industries will be affected. The effect could also be on the banking sector, which has been providing credit. Therefore, various parties should support this industry. Do not let the interested "parties" defend Sontoloyo debtors, who do not pay their debts, but still want to control their vehicles that have not been paid off.

Even though after the Constitutional Court decision regarding fiduciary was still able to withdraw vehicles, the leasing party will be more careful in executing its fiduciary rights. So, this Constitutional Court decision is not an end for leasing. However, leasing will be more selective in order to avoid the sontoloyo debtor trap. Imagine, if the debtor is difficult to contact, the vehicle is not there - maybe pawned or sold - why don't you go to court for execution.

In the short term, at least the Constitutional Court can write to all courts related to fiduciary cases to issue a ruling as soon as possible. No worries, just a motorcycle business, which has sometimes been stripped down. Or, if necessary, amend the fiduciary law to suit 
these changing conditions. Or, it is better to be included in the "omnibus law" in the financial sector.

This was done solely so that the business climate is full of certainty and is market friendly for the growth and development of the multi-finance industry - which will have a positive impact on the economy. Remember, the multi industry does not stand alone. There is banking, there is the automotive industry as well as supporting industrial sub-sectors which are not only a matter of IDR 443 trillion which is the portfolio of this automotive sector. Don't let the financial industry fend for itself. OJK as a regulator must provide support for the development of this multi. At least not always blame the multi if there is a dispute between bad debtors and leasing.

\section{Conclusion}

Based on the research and discussion above, the implementation of rights and obligations between creditors and creditors may still cause problems or have positive and negative consequences, depending on each party's response and interpretation. The simpler the conclusion is:

a) Creditors must obtain the Court's permission before executing the object of financing.

b) Self-execution without court permission may be carried out if the debtor submits voluntarily.

c) Good faith remains the main guarantee in consumer financing agreements.

Based on the above conclusions, the authors provide suggestions:

1) Creditors carry out appropriate surveys so that debtors do not default.

2) In the consumer financing agreement, a default is written which results in the execution of the object of financing.

3) The parties must meet in an effort to mediate in the event of problems related to consumer financing.

\section{References}

[1] Kitab Undang-undang Hukum Perdata (KUHPerdata). Jakarta: Gama Press, 2010.

[2] "Putusan Mahkamah Konstitusi Nomor 18/PUU-XVII/2019.".

[3] S. Hadi, Metodologi Riset. Yogyakarta: Pustaka Pelajar, 2015.

[4] "Keputusan Presiden Republik Indonesia Nomor 61 Tahun 1988 tentang Lembaga Pembiayaan.”.

[5] "Keputusan Menteri Keuangan Republik Indonesia Nomor : 446/KMK.017/1988 tentang Ketentuandan Tata Cara Pelaksanaan Lembaga Pembiayaan.” .

[6] "Keputusan Menteri Keuangan Republik Indonesia Nomor 172/KMK.06/2002 tentang Perusahaan Pembiayaan.”.

[7] "Peraturan Otoritas Jasa Keuangan, POJK No:1/POJK.07/2013.".

[8] A. R. Wulandari, "Menyoal larangan leasing tarik kendaraan tanpa pengadilan," Lokadata, 2020. https://lokadata.id/artikel/menyoal-larangan-leasing-tarik-kendaraantanpa-pengadilan.

[9] P. Yoga, "Pascaputusan MK tentang Fidusia, Leasing Masih Bisa Tarik Kendaraan," Infobanknews.com, 2020. https://infobanknews.com/headline/pascaputusan-mktentang-fidusia-leasing-masih-bisa-tarik-kendaraan/. 